\title{
Geniculate Ganglion
}

National Cancer Institute

\section{Source}

National Cancer Institute. Geniculate Ganglion. NCI Thesaurus. Code C12721.

A cluster of cranial nerve VII cell bodies located within the petrous temporal bone at the facial genu; it contains sensory nerve cell bodies for taste (from chorda tympani) and external ear sensation (from sensory auricular branch). 